\title{
Secondary Liability Under Section 10(b) of the Securities Act of 1934
}

\author{
Daniel R. Fischel ${ }^{\dagger}$
}

Various common law doctrines have played a central role in the development of a federal common law under section 10(b) of the Securities Exchange Act of $1934^{1}$ and rule $10 \mathrm{~b}-5 .^{2}$ The existence of an implied private right of action for danages under section $10(\mathrm{~b})$ and rule $10 \mathrm{~b}-5$, for example, was originally predicated upon the tort law maxim, Ubi jus, ibi remedium - where there is a right, there is a reenedy. ${ }^{3}$ Courts have similarly relied on criminal and tort common law doctrines in imposing secondary liability ${ }^{4}$ on peripheral defendants who do not themselves violate the express prohibition of a statute, but who have some connection with the primary wrongdoer.

$\dagger$ Assistant Professor of Law, Northwestern University School of Law. B.A. 1972, Cornell University; J.D. 1977, University of Chicago.

The author wishes to thank Dean David S. Ruder and Professor Stephen Presser of Northwestern University School of Law, Professor Frank H. Easterbrook of the University of Chicago Law School, and Professor Michael P. Dooley of the University of Virginia Law School for their extremely helpful comments and suggestions. The views expressed herein, however, are solely those of the author.

1. 15 U.S.C. \& 78j(b) (1976). Section 10(b) reads in pertinent part: "lt shall be unlawful for any person, directly or indirectly, . . . (b) To use or employ, in connection with the purchase or sale of any security . . . any manipulative or deceptive device or contrivance . . . ."

2. 17 C.F.R. \& 240.10b-5 (1980). Rule $10 \mathrm{~b}-5$ provides in relevant part that it is unlawful:

(a) To employ any device, scheine, or artifice to defraud, (b) To make any untrue statement of a inaterial fact or to ounit to state a material fact necessary in order to make the statements made, in the light of the circumstances under which they were made, not misleading, or (c) To engage in any act, practice, or course of business which operates or would operate as a fraud or deceit upon any person, in connection with the purchase or sale of any security.

3. See Kardon v. National Gypsum Co., 69 F. Supp. 512 (E.D. Pa. 1946).

4. Secondary liability under the securities laws has two distinct meanings. First, the term is used to describe the judicially implied civil liability which has been imposed on defendants who liave not themselves been held to have violated the express prohibition of the securities statute at issue, but who have soine relationship with the primary wrongdoer. Courts have imposed this type of secondary liabihity on defendants who aid and abet, conspire with, or employ a defendant who does violate the express prohibition of a statute. The focus of this Article is with this type of secondary liability.

The second usage of the term secondary liabihity is the liability expressly imposed on "controlling persons" by $\S 15$ of the Securities Act of 1933, 15 U.S.C. \$§ 77a-77aa (1976), and § 20(a) of the Securities Exchange Act of 1934, 15 U.S.C. $\$ \S 78 \mathrm{a}-78 \mathrm{kk}$ (1976).

The leading discussion of the scope of both types of secondary liability prior to the Supreme Court's recent restrictive interpretations of the securities laws is Ruder, Multiple Defendants in Securities Law Fraud Cases: Aiding and Abetting, Conspiracy, In Pari Delicto, Indemnjication, and Contribution, 120 U. PA. L. REv. 597 (1972). 
The United States Supreme Court has recently stated, however, that reliance on tort law principles as a justification for implying a private right of action is entirely "misplaced"s because the "central inquiry" is "whether Congress intended to create, either expressly or by implication, a private cause of action." Emphasizing the importance of statutory language and structure, and expressly disavowing the approach of earlier cases, the Court has rejected attempts to imply private rights of action under various provisions of the securities laws.

The emphasis on statutory language and structure in discerning congressional intent is also evident in recent Supreme Court decisions narrowing the substantive scope of the federal securities laws. ${ }^{8}$ Thus, the Court in recent years has repeatedly reversed lower courts which have expansively interpreted the federal securities laws by glossing over the operative words of statutory provisions. ${ }^{9}$

Despite this restrictive trend in the Supreme Court, lower courts, relying on various common law doctrines, have contmued to expansively interpret the scope of the securities laws in the area of secondary hability without express statutory mandates for doing so. ${ }^{10}$ Every court of appeals that has faced the issue, for example, has held that a defendant can be liable for "aiding and abettimg" a violation by another defendant of section $10(\mathrm{~b})$ and rule $10 \mathrm{~b}-5,{ }^{11}$ the provisions under which the vast niajority of secondary liability cases arise, ${ }^{12}$ even though the literal language of section 10(b) contains no such prohibition. Several

5. Touche Ross \& Co. v. Redington, 442 U.S. 560,568 (1979).

6. Id. at 575. See also Transamerica Mortgage Advisors, Inc. v. Lewis, 444 U.S. 11 (1979) (the "dispositive question" is whether Congress intended to create a private remedy).

7. Transamerica Mortgage Advisors, Inc. v. Lewis, 444 U.S. 11 (1979); Touche Ross \& Co. v. Redington, 442 U.S. 560 (1979); Piper v. Chris-Craft Indus., Inc., 430 U.S. 1 (1977). In these cases the Court rejected the rationale of J.I. Case Co. v. Borak, 377 U.S. 426 (1964), where a private remedy was impled to effectuate the renedial purposes of a statute. Transamerica Mortgage Advisors, Inc. v. Lewis, 444 U.S. 11, 15-16; 442 U.S. at 576-78. The Court has also rejected the analysis in Cort v. Ash, 422 U.S. 66 (1975), to the extent it permitted implication of a private cause of action even though Congress did not intend such a result. 442 U.S. at 575-76. See also 444 U.S. at 23-24; notes 66-79 and accompanying text infra.

8. Aaron v. SEC, 100 S. Ct. 1945 (1980); Chiarella v. United States, 445 U.S. 222 (1980); International Bhd. of Teamsters v. Daniel, 439 U.S. 551 (1979); Santa Fe Indus., Inc. v. Green, 430 U.S. 462 (1977); TSC Indus., Inc. v. Northway, Inc., 426 U.S. 438 (1976); Ernst \& Ernst v. Hochfelder, 425 U.S. 185 (1976); Rondeau v. Mosinee Paper Corp., 422 U.S. 49 (1975); Blue Chip Stamps v. Manor Drng Stores, 421 U.S. 723 (1975). See also SEC v. Sloan, 436 U.S. 103 (1978).

9. E.g., Santa Fe Indus., Inc. v. Green, 430 U.S. 462 (1977); Ernst \& Ernst v. Hochfelder, 425 U.S. 185 (1976); Blue Chip Stamps v. Manor Drug Stores, 421 U.S. 723 (1975).

10. See Part I infra.

11. E.g., Monsen v. Consolidated Dressed Beef Co., 579 F.2d 793 (3d Cir. 1978), cert. denied, 439 U.S. 930 (1979); Rolf v. Blyth, Eastman Dillon \& Co., 570 F.2d 38 (2d Cir.), cert. denied, 439 U.S. 1039 (1978); Woodward v. Metro Bank of Dallas, 522 F.2d 84 (5th Cir. 1975); SEC v. Coffey, 493 F.2d 1304 (6th Cir. 1974), cert. denied, 420 U.S. 908 (1975).

12. Secondary liability has also been imposed, however, under other provisions of the seeurities Iaws. See notes 35-38 and accompanying text infra. 
courts have similarly held that a defendant can be liable for "conspiring with" another defendant who violates the securities laws. ${ }^{13}$ Finally, numerous courts have held that einployers of defendants who violate the securities laws can themselves be hable under a respondeat superior theory. ${ }^{14}$

As a result of the wholesale incorporation of these cominon law doctrines into the federal securities laws, courts have increasingly held that numerous types of defendants can be secondarily hable when they have some connection with a defendant who has been found to have violated an express prohibition of the securities laws. These defendants have included banks, ${ }^{15}$ stock exchanges, ${ }^{16}$ accountants, ${ }^{17}$ lawyers, ${ }^{18}$ and underwriters, ${ }^{19}$ as well as employers or supervising einployees generally. 20

The thesis of this Article is that the theory of secondary liability is no longer viable im hight of recent Supreme Court decisions strictly imterpreting the federal securities laws. These cases make clear that the question of hability for all defendants must be determmed by the language, structure, and legislative history of the relevant statutes. Since lower courts have relied instead upon various common law doctrines to impose liability upon defendants alleged to have aided and abetted, conspired with, or einployed so-called "primary" wrongdoers, their decisions must now be reevaluated. When liabihty is determmed by reference to the language and structure of securities statutes, far fewer defendants will face hability under the federal securities laws.

Part I of this Article will exainine the development of aiding and abettimg, conspiracy, and respondeat superior liability in the current state of the law of section 10(b). Part II will demonstrate, using the implied private right of action cases as an analogy, that tort and crimi-

13. E.g., Dasho v. Susquehanna Corp., 380 F.2d 262 (7th Cir.), cert. denied, 389 U.S. 977 (1967); Pettit v. American Stock Exch., 217 F. Supp. 21 (S.D.N.Y. 1963); Kardon v. National Gypsum Co., 69 F. Supp. 512 (E.D. Pa. 1946).

14. E.g., Paul F. Newton \& Co. v. Texas Commerce Bank, 630 F.2d 1111 (5th Cir. 1980). Marbury Mgmt., Inc. v. Kohn, 629 F.2d 705 (2d Cir. 1980), cert. denied sub nom. Wood Walkey \& Co. v. Marbury Mgmt., Inc., 149 U.S.L.W. 3409 (U.S. Dec. 1, 1980); Holloway v. Howerdd, 536 F.2d 690 (6th Cir. 1976).

15. E.g., Monsen v. Consolidated Dressed Beef Co., 579 F.2d 793 (3d Cir. 1978), cert. denied, 439 U.S. 930 (1979); Rosen v. Dick [1974-1975 Transfer Binder] FED. SEC. L. REP. (CCH) \94,786 (S.D.N.Y. 1974); Pettit v. American Stock Exch., 217 F. Supp. 21 (S.D.N.Y. 1963).

16. E.g., Pettit v. American Stock Exch., 217 F. Supp. 21 (S.D.N.Y. 1963).

17. E.g., Kestenbaum v. Emerson, [1979-1980 Transfer Binder] Fed. SeC. L. REP. (CCH) I 97,330 (S.D.N.Y. Mar. 20, 1980); H.L. Green Co. v. Childree, 185 F. Supp. 95 (S.D.N.Y. 1960).

18. E.g., SEC v. Coven, 581 F.2d 1020 (2d Cir. 1978); SEC v. Spectruin, Ltd., 489 F.2d 535 (2d Cir. 1973); SEC v. National Student Marketing Corp., 457 F. Supp. 682 (D.D.C. 1978).

19. E.g., IIT v. Cornfeld, 619 F.2d 909 (2d Cir. 1980).

20. E.g., Marbury Mgmt., Inc. v. Kohn, 629 F.2d 705 (2d Cir. 1980), cert. denied sub nont. Wood Walkey \& Co. v. Marbury Mgmt., Inc., 49 U.S.L.W. 3409 (U.S. Dec. 1, 1980); Rolf v. Blyth, Eastman Dillon \& Co., 570 F.2d 38 (2d Cir.), cert. denied, 439 U.S. 1039 (1978); Holloway v. Howerdd, 536 F.2d 690 (6th Cir. 1976). 
nal law doctrines should not serve as the basis for the imposition of secondary liability. Part III will further demonstrate that when congressional intent, as measured by statutory language, structure, and history, is used as the touchstone for determining the scope of liability, the imposition of secondary liability cannot be justified. Because aiding and abetting, conspiracy, and respondeat superior should no longer be recognized as valid theories of recovery, peripheral defendants in securities cases can be liable only if they engage in a "manipulative or deceptive" practice within the ineaning of section $10(\mathrm{~b})$ or engage in conduct that violates some other express statutory prohibition. Thus, Part IV will analyze the appropriate limits of hability under section 10(b) and selected other provisions of the federal securities laws.

I

The Development of Secondary Liability and the CURRENT STATE OF THE LAW

Courts have imposed secondary liability based on a variety of theories, including aiding and abetting, conspiracy, and respondeat superior. The development of each of these doctrines is examined below.

\section{A. Aiding and Abetting Liability}

The leading case establishing aiding and abetting liability and, indeed, the leading secondary liability case in general is the district court opinion in Brennan v. Midwestern United Life Insurance Co ${ }^{21}$ Because the analysis im Brennan reveals a great deal about the cominon law, nonstatutory basis of secondary liability, it is worthy of careful scrutiny.

The complaimt in Brennan alleged that a defendant corporation, Midwestern, was liable under section $10(\mathrm{~b})$ and rule $10 \mathrm{~b}-5$ for aiding and abetting an alleged violation of these provisions by a broker, Dobich, who engaged in a fraudulent scheine in the sale of Midwestern stock. The complaimt alleged that Midwestern was aware of Dobich's activities, but failed to report the activities to the Indiana Securities Commission or to the Securities and Exchange Commission. By permitting the fraudulent scheine to continue, the coinplaint alleged, Midwestern encouraged the continuation of the scheine and benefited by the artificial build-up of the inarket for its stock. ${ }^{22}$

Midwestern attacked the sufficiency of the coinplaint, arguing, inter alia, that "there is nothing in the statute indicating a Congressional

21. 259 F. Supp. 673 (N.D. Ind. 1966) (motion to dismiss denied), 286 F. Supp. 702 (N.D. Ind. 1968) (on merits after trial), affd, 417 F.2d 147 (7th Cir. 1969), cert. denied, 397 U.S. 989 (1970).

22. 259 F. Supp. at 675 . 
intent to impose civil liability on persons aiding and abetting violations of Section 10(b) and Rule 10b-5."23 Midwestern also argued that the relevant legislative history showed Congress chose not to prohibit aiding and abetting since it had declined to adopt ainendments to the securities laws explicitly making aiding and abetting actionable under section $10(\mathrm{~b}){ }^{24}$

The district court, although acknowledging that there was nothing in the statute or its legislative history indicating a congressional intent to impose aiding and abetting liability, nevertheless held that an aider and abettor could be liable under the section and the rule. Relying heavily upon section 876 of the Restatement of Torts, ${ }^{25}$ the court stated that "general principles of the law should continue to guide the developinent of federal common law reinedies under section 10(b) and rule 10b-5."26 Implying liability for aiding and abetting based on common law tort principles, in the court's view, was nothing more than a "logical and natural complement"27 to the implication of a private right of action under rule 10b-5, which was also developed from general principles of tort law. ${ }^{28}$ Having incorporated the tort law concept of aiding and abetting liability into section $10(\mathrm{~b})$ and rule 10b-5, the court declined to dismiss the complaint.

Brennan's underlying rationale was immediately followed by other courts. ${ }^{29}$ These courts, also reasoning from the Restateinent of Torts,

\section{Id. at 680 .}

24. Id. at 677. See note 103 and accompanying text infra.

25. Section 876 of the Restatement OF TORTS provides:

For harm resulting to a third person from the tortious conduct of another, one is subject to habihity if he ... (b) knows that the other's conduct constitutes a breach of duty and gives substantial assistance or encouragement to the other so to conduct himself, or (c) gives substantial assistance to the other in accomplishing a tortious result and his own conduct, separately considered, constitutes a breach of duty to the third person.

RESTATEMENT OF TORTS $\$ 876$ (1939).

26. 259 F. Supp. at 680 .

27. Id.

28. The court rejected the argument that aiding and abetting is not prohibited by $\S 10(\mathrm{~b})$ and rule $10 \mathrm{~b}-5$ because there is no evidence that Congress intended to prohibit such conduct by referring to the rejection of comparable arguments against implying a private right of action.

[D]efendant points out that there is nothing in the statute indicating a Congressional intent to impose civil hability on persons aiding and abetting violations of Section 10 (b) and Rule $10 \mathrm{~b}-5$. But, likewise, one can search the statute in vain for language indicating that a violator of Section 10 (b) and Rule $10 \mathrm{~b}-5$ should be liable in a civil action for damages. Such liability was developed by the courts on general principles of tort law. Judge Kirkpatrick in the Kardon case, . . . cited the Restatement, Torts \$ 286 (1939) in finding civil liability for the violation of Section 10(b). Sucl liability was there rcsted upon the maxim, Ubi jus, ibi remedium-Where there is a right, there is a remedy. This is the rationale upon which the Kardon doctrine has been adopted by the court of appeals. Appropriate general principles of law should continue to guide the developinent of federal common law remedies under Section 10(b) and Rule 10b-5.

Id. (citations oinitted).

29. E.g., SEC v. Coffey, 493 F.2d 1304 (6th Cir. 1974), cert. denied, 420 U.S. 908 (1975); Landy v. FDIC, 486 F.2d 139 (3d Cir. 1973). See also IIT v. Cornfeld, 619 F.2d 909 (2d Cir. 
held that peripheral defendants who knew or should have known of a fraud and rendered substantial assistance to the primary wrongdoer could be liable as aiders and abettors.

\section{B. Conspiracy Liability}

Relying upon the tort and criminal common law concept of conspiracy, a few lower courts have also held that peripheral defendants could be liable under the securities laws if they "conspired" with the primary violator. ${ }^{30}$ Indeed, the case in which an implied private right of action under section 10(b) was first recognized, Kardon v. National Gypsum Co., ${ }^{31}$ involved a cause of action alleging conspiracy.

In Kardon, shareholders of a closely held company sold their shares to certain other shareholders. These purchasing shareholders allegedly had previously entered into an agreenent to resell these shares to an unrelated corporation, National, at a higher price. The selling sliareholders then brought an action against the purchasing shareholders under rule $10 \mathrm{~b}-5$ for failure to disclose this alleged agreement to resell at a higher price. National was joined as a defendant because it allegedly "conspired" with the purchasing shareholders. The court held that National could be hable as a conspirator if it knew of the purchasing shareholders' intention not to disclose the agreement to resell.

One of the inost cominon areas where liability has been imposed under a conspiracy theory is in the sale of control cases. In Dasho v. Susquehanna Corporation, ${ }^{32}$ for example, plaintiff shareholders alleged, in a derivative action under section 10(b) and rule 10b-5, that the officers and directors had conspired to defraud the corporation in a scheine in which insiders had sold control of the corporation to a second corporation which had subsequently merged into the first corporation. The court held that this inerger constituted a sale of securities by which the first corporation was defrauded. The court further held that one director, Lauhoff, who was not involved in the merger since he sold his stock and resigned as a director (allegedly in furtherance of the fraudulent scheine), was nevertheless liable as a conspirator. ${ }^{33}$ Other

1980); Edward J. Mawod \& Co. v. SEC, 591 F.2d 588 (10th Cir. 1979); Monsen v. Consolidated Dressed Beef Co., 579 F.2d 793 (3d Cir. 1978), cert. denied, 439 U.S. 930 (1979); Rolf v. Blyth, Eastman Dillon \& Co., 570 F.2d 38 (2d Cir.), cert. denied, 439 U.S. 1039 (1978).

30. E.g., Dasho v. Susquehanna Corp., 380 F.2d 262 (7th Cir.), cert. denied, 389 U.S. 977 (1967); Texas Continental Life Ins. Co. v. Dunne, 307 F.2d 242 (6th Cir. 1962); Kardon v. National Gypsum Co., 69 F. Supp. 512 (E.D. Pa. 1946).

31. 69 F. Supp. 512 (E.D. Pa. 1946).

32. 380 F.2d 262 (7th Cir.), cert. denied, 389 U.S. 977 (1967).

33. The court stated:

Lauhoff's sale of his stock and his resignation as a director were allegedly two of the overt acts done by him in furtherance of the conspiracy. Thus, having allegedly joined 
courts liave upheld allegations of conspiracy liability under similar circumstances. ${ }^{34}$

\section{Respondeat Superior Liability}

Section 15 of the Securities Act of $1933^{35}$ and section 20(a) of the Securities Exchange Act of $1934^{36}$ each impose liability on those "controlling persons" whio control the primary wrongdoer. Both sections, however, provide a good faith defense to control person liability. ${ }^{37}$ As a general rule, this defense shields a person from liability if he can show that he exercised reasonable internal supervision against securities violations. ${ }^{38}$

To preclude employers from relying upon this good faith defense, plamtiffs have sued these defendants under section $10(\mathrm{~b})$ using the theory of respondeat superior. Under this common law doctrine, employers are strictly liable for the improper acts of their einployees committed within the scope of their employment. ${ }^{39}$ The statutory good faitl defense provided by sections 15 and 20(a), therefore, is unavailable to defendants in actions brought under a respondeat superior theory.

Employer defendants, to avoid strict liability under respondeat superior, have consistently argued that the controlling persons sections with their good faith defense are the exclusive method of imposing liability on employers under the securities acts. While some courts have accepted this argument, ${ }^{40}$ the majority of courts of appeals have held that the controlling persons provisions do not preclude the inposition

the conspiracy and taken steps to assure its success, Lauhoff is responsible for the acts of his co-conspirators in furtherance of said conspiracy.

Id. at 267 n.2.

34. E.g., Herpich v. Wilder, 430 F.2d 818 (5th Cir. 1970), cert. denied, 401 U.S. 947 (1971); Shell v. Hensley, 430 F.2d 819 (5th Cir. 1970).

35. 15 U.S.C. $\$ 770$ (1976).

36. $I d . \S 78 \mathrm{t}$.

37. Section 15 of the 1933 Act, 15 U.S.C. $\$ 77$ o (1976) provides that a controlling person shall be liable "unless the controlling person had no knowledge of or reasonable ground to believe in the existence of the facts by reason of which the liability of the controlled person is alleged to exist." Section 20(a) of the 1934 Exchange Act, 15 U.S.C. \& 78t(a) (1976), similarly provides that a controlling person shall be liable "unless the controlling person acted in good faith and did not directly or indirectly induce the act or acts constituting the violation or cause of action."

38. E.g., Zweig v. Hearst Corp., 521 F.2d 1129, 1134-35 (9th Cir.), cert. denied, 423 U.S. 1025 (1975).

39. Kerbs v. Fall River Indus., Inc., S02 F.2d 731 (10th Cir. 1974); RestatemENT (SECOND) OF AGENCY $\S 257$ (1958).

40. E.g., Christoffel v. E.F. Hutton \& Co., 588 F.2d 665 (9th Cir. 1978); Rochez Bros., Inc. v. Rhoades, 527 F.2d 880 (3d Cir. 1975); Zweig v. Hearst Corp., 521 F.2d 1129 (9th Cir.), cert. denied, 423 U.S. 1025 (1975); Klapmeier v. Telecheck Int'l, Inc., 482 F.2d 247 (8th Cir. 1973). 
of respondeat superior liability, apparently through federal law. ${ }^{41}$

The recent Second Circuit case of Marbury Management, Inc. $v$. $K o h n^{42}$ is illustrative of this majority view. In Marbury, a brokerage firm's employee committed a securities fraud on certain purchasers. Plaintiffs sued the employee as well as the brokerage firm. The court lield that the brokerage firm could be liable, under both the controlling person provision of section 20(a) and under respondeat superior. The court rejected the exclusivity argument, stating that, "[T]here is no warrant for believing that Section 20(a) was intended to narrow the remedies of the customers of brokerage houses or to create a novel defense in cases otherwise governed by traditional agency principles." $43 \mathrm{Sev}-$ eral provisions of the Restatement of Agency were cited by the court. ${ }^{44}$ Having held that respondeat superior liability is not precluded by the controlling persons provisions, the court concluded that "the special good faitl defense afforded by the last clause of Section 20(a) is unavailable."45 By recognizing strict liability under respondeat superior, the Second Circuit and other circuits which have adopted the sane view liave effectively eliminated the good faith defense provided by the statute.

\section{The Supreme Court and Secondary Liability}

The Supreme Court has never faced the issue of whether secondary liability is a valid theory under section $10(\mathrm{~b})$ and rule $10 \mathrm{~b}-5$. The Court's decision in Ernst \& Ernst v. Hochfelder, ${ }^{46}$ however, suggests that the Court might not recognize any of the various forms of secondary liability as valid theories of recovery.

The Seventh Circuit, in Hochfelder, had held that an accountimg firm whicli liad negligently failed to discover a fraud of the primary

41. See also Paul F. Newton \& Co. v. Texas Commerce Bank, 630 F.2d 111 (5th Cir. 1980). Marbury Mgmt. Inc. v. Kohn, 629 F.2d 705 (2d Cir. 1980), cert. denied sub nom. Wood Walker \& Co. v. Marbury Mgmt., Inc., 49 U.S.L.W. 3409 (U.S. Dec. 1, 1980); Holloway v. Howerdd, 536 F.2d 690 (6th Cir. 1976); Carras v. Burns, 516 F.2d 251 (4th Cir. 1975); Bird v. Ferry, 497 F.2d 112 (5th Cir. 1974); Senott v. Rodman \& Renshaw, 474 F.2d 32 (7th Cir.), cert. denied, 414 U.S. 926 (1973); Richardson v. MacArthur, 451 F.2d 35 (10th Cir. 1971). These other cases do not specifically state that they are relying upon federal law. Because there is no mention of any relevant state law, however, nor any discussion of the exercise of pendent jurisdiction, these courts appear to base their imposition of respondeat superior liability upon federal law.

42. 629 F.2d 705 (2d Cir. 1980), cert. denied sub nom. Wood Walker \& Co. v. Marbury Mgmt., Inc., 49 U.S.L.W. 3409 (U.S. Dec. 1, 1980).

43. Id. at 716. The logical conclusion that follows from this statement is that $\$ 20(\mathrm{a})$ does not supplant respondeat superior liability under state law. The Marbury court, in contrast, like the other courts that have imposed respondeat superior hability, based its holding on federal law. See note 41 and accompanying text supra. It does not follow, however, that because Congress did not intend to narrow the remedies available at common law, it meant to create a federal remedy under $\S 10(b)$.

44. Id. The court cited Restatement (SECOND) of Agency $\$ \$ 228,229,257,258,261,262$, and 265 (1958).

45. 629 F.2d at 716.

46. 425 U.S. 185 (1976). 
wrongdoer could be liable as an aider and abettor. ${ }^{47}$ The Supreme Court reversed, but based its holding on a need for scienter, ${ }^{48}$ and did not reach the question of whether a defendant could be liable for aiding and abetting. In an important footnote, however, the Court stated:

In view of our holding that an intent to deceive, manipulate, or defraud is required for hability, under section 10(b) and Rule 10b-5, we need not consider whether civil liability for aiding and abetting is appropriate under the section and the Rule. . . ${ }^{49}$

Although the Court expressly reserved the issue of whether aiding and abetting is a proper theory under section $10(\mathrm{~b})$ and rule $10 \mathrm{~b}-5$, its approach nevertheless casts some doubt on the continued viability of aiding and abetting liability. The Supreme Court reversed the Seventh Circuit's holding that the accounting firm was liable as an aider and abettor because the plaintiff had failed to allege that it had acted with scienter as required by the "manipulative or deceptive" language of section 10(b). However, under a strict aiding and abetting analysis, it is irrelevant whether an aider and abettor has engaged in a manipulative or deceptive practice within the meaning of section $10(\mathrm{~b})$. What is relevant is whether the primary violator engaged in such a practice. The critical inquiry then would be whether the secondary defendant aided and abetted in the commission of the violation. ${ }^{50}$ By holding that the accounting firm was not hable under the section and the rule because it did not engage in a "manipulative or deceptive" practice, and by not considering whether the accounting firm could otherwise be hable as an aider and abettor, the Court imphicitly held that aiding and abetting liability does not exist apart from hability that could be inposed for a direct violation.

While the Court in Hochfelder only questioned the soundness of aiding and abetting liability, its analysis applies equally to conspiracy and respondeat superior liability. These latter forms of secondary liability, like aiding and abetting, have been derived froin common law concepts rather than the language of section $10(\mathrm{~b})$. Morc important, if Hochfelder stands for the proposition that a defendant cannot be liable under section 10(b) and rule 10b-5 unless he has engaged in a "manipulative or deceptive" practice within the meaning of section 10(b), the current validity of all forms of secondary habihty is, at the very least, im doubt.

47. Hochfelder v. Ernst \& Ernst, 503 F.2d 1100 (7th Cir. 1974), rev'd, 425 U.S. 185 (1976).

48. The Court explicitly refused to decide whether reckless conduct was sufficient to satisfy the scienter standard. 425 U.S. at 193 n. 12.

49. Id. at 191 n.7.

50. At common law, for example, a party could be liable for selling burglary tools to a burglar even though he himself did not commit the actual burglary. 
II

The Use of Tort and Criminal Law Doctrines as a

BASIS FOR IMPOSING SECONDARY LIABILITY:

THE IMPLIED RIGHT OF ACTION

ANALOGY

The existence of implied remedies under the securities laws, like the existence of secondary liability, arose from incorporation of common law doctrines into the federal securities laws. ${ }^{51}$ Indeed, the imposition of secondary liability based upon tort concepts was origmally justified by the comparable reliance on tort law in the creation of implied remedies. ${ }^{52}$ The validity of relying on tort law as the basis for implied private rights of action, therefore, is directly relevant to the propriety of employing the same approach in the secondary liability context.

\section{A. The Use of Tort Law and the Implied Remedies Doctrine}

The tort law origins of implied remedies under the securities laws are clear. Kardon v. National Gypsum Co., ${ }^{53}$ the case first establishing a private right of action under section 10(b) and rule 10b-5, is illustrative. There the court expressly rehed upon section 286 of the Restatement of Torts $^{54}$ in rejecting the argument that Congress failure to provide an express remedy when such remedies were provided for in other sections demonstrated that Congress did not intend for one to exist. Although the court conceded that the argument might be persuasive, "[w]ere the whole question one of statutory interpretation," it concluded that the existence of other express remedies was insufficient to manifest an imtent "to deny a remedy and to wipe out a hability which, normally, by virtue of basic principles of tort law accompanies the doing of the prohibited act." 55

The court in Kardon, therefore, did not find that Congress intended to create a private remedy in section 10(b). Indeed, the court's concession suggests that had it viewed the inquiry as resting solely

51. Kardon v. National Gypsum Co., 69 F. Supp. 512 (E.D. Pa. 1946). See notes 53-55 and accompanying text infra.

52. See note 28 supra.

53. 69 F. Supp. 512 (E.D. Pa. 1946).

54. Id. at 513. Section 286 provides in part that:

The violation of a legislative enactment by doing a prohibited act, or by failing to do a required act, makes the actor hable for an mvasion of an mterest of another if: (a) the intent of the enactment is exclusively or im part to protect an imterest of the other as an individual; and (b) the imterest invaded is one which the enactment is intended to protect ....

RESTATEMENT OF TORTS $\$ 286$ (1934).

55. $69 \mathrm{~F}$. Supp. at 514. This is the same reasoning that the Supreme Court used in first implying a private remedy. See Texas \& P. Ry. Co. v. Rigsby, 241 U.S. 33 (1916). 
upon whether Congress intended to create such a remedy, it would have reached the opposite conclusion. Only by rehance upon tort law principles, rather than congressional intent, did the court imply a private remedy under section $10(\mathrm{~b})$ and rule $10 \mathrm{~b}-5$.

\section{B. The Supreme Court's Shift Away from Tort Law as a Basis for Implying Private Remedies in Securities Cases:} From Borak to Piper

Although numerous lower courts adopted the tort law rationale of Kardon as a basis for implying private remedies, ${ }^{56}$ the Supreme Court has followed a different approach. In J.I. Case Co. v. Borak, ${ }^{57}$ the Court held that an implied private right of action existed under section 14(a) of the Securities Exchange Act. ${ }^{58}$ The Court reasoned that since "[p]rivate enforcement of the proxy rules provides a necessary supplement to Commission action," 59 a private remedy was necessary to enforce the statutory scheine.

The enforcement rationale of Borak was narrowed in Cort $v$. $A s h,{ }^{60}$ where no implied private right of action was found under a federal election statute. ${ }^{61}$ The Court established a four part test for determining whether to imply a private right of action: (1) whether the plamtiff is part of a class for whose benefit the statute was enacted; (2) whetler there is any relevant legislative intent; (3) whether the imphication of a remedy is consistent with the legislative scheme; and (4) whether the cause of action is traditionally relegated to state law. ${ }^{62}$ Applying this test, the Court in Piper v. Chris-Craft Industries, Inc. ${ }^{63}$ held that a defeated tender bidder cannot maintain a dainage action against the successful bidder or the target under section 14(e) of the Williams Act. ${ }^{64}$

Neither Borak nor Cort, therefore, applied the tort law rationale of Kardon. The analysis in thcse cases, however, suffers from the same defect. Both the enforcement rationale of Borak and the four part test

56. E.g., Goodman v. H. Hentz \& Co., 265 F. Supp. 440 (N.D. Ill. 1967) (implication of private remedy under Commodity Excliange Act); Remar v. Clayton Sec. Corp., 81 F. Supp. 1014 (D. Mass. 1949) (implication of private remedy under $\S 7$ of the Securities Exchange Act).

57. 377 U.S. 426 (1964).

58. Section 14(a) of the 1934 Act, 15 U.S.C. $\$ 78$ n(a) (1976) makes it unlawful for manage* ment or others to obtam authorization for corporate action by ineans of deceptive or inadequate disclosure in proxy solicitations.

59. 377 U.S. at 432.

60. 422 U.S. 66 (1975).

61. 18 U.S.C. $\$ 610$ (1970) (repealed 1976). The statute made it a criminal penalty for corporations to make political contributions under certaim circuinstances.

62. 422 U.S. at 78.

63. 430 U.S. 1 (1977).

64. 15 U.S.C. $\$ 78 n(e)$ (1976). 
in Cort and Piper, like the tort rationale of Kardon, allow courts to imply private rights of action without any finding that Congress intended to confer such a remedy. Consequently, these cases invite courts to engage in judicial lawmaking and create federal statutory reinedies even where Congress may never have imtended that such reinedies exist. ${ }^{65}$

\section{The Rejection of Tort Law as a Basis for Implying Private Remedies in Securities Cases: Touche \\ Ross and Transainerica}

Recent Supreine Court decisions have severely limited the availability of implied private damage remedies in securities cases. While the Court has repeatedly recognized ${ }^{66}$ that there is an implied reinedy under section 10 (b) and rule $10 \mathrm{~b}-5$, it nevertheless lias repudiated the rationale of the Kardon case. Thus, the Court in Touche Ross \& Co. $v$. Redington $^{67}$ dismissed arguinents to imply a private right of action under section 17(a) of the Securities and Excliange Act of $1934^{68}$ based upon tort principles as "entirely imsplaced."69 Rather, the Court stated, the question "of the existence of a statutory cause of action is .. . one of statutory construction."70 The Court furtlier einpliasized that simply because a federal statute lias been violated and a person injured does not automatically mean a private riglit of action will be conferred in favor of that person. "1 "Tlie ultimate question," stated the Court, "is one of Congressional intent, not one of whetler this Court thinks it can improve upon the statutory scheine that Congress enacted into law."

The emphasis on statutory construction im determining the existence of an implied remedy is also evident in Transamerica Mortgage Advisors $v$. Lewis. ${ }^{73}$ There the Court stated that what inust be ascertained "is whetlier Congress imtended to create the private reinedy as-

65. This point was made in Justice Powell's dissenting opinion in Cannon v. University of Chicago, 441 U.S. 677, 740-41 (1979).

66. The Court, while never facing the issue directly, has stated that the existence of an iniplied private right of action under $\S 10(\mathrm{~b})$ and rule $10 \mathrm{~b}-5$ is "well established." Ernst \& Ernst $\mathrm{v}$. Hochfelder, 425 U.S. 185, 196 (1976). See also Superintendent of Ins. v. Bankers Life \& Cas. Co., 404 U.S. 6,13 n.9 (1971).

67. 442 U.S. 560 (1979).

68. 15 U.S.C. $\$ 78 \mathrm{q}(\mathrm{a})(1976)$.

69. 442 U.S. at 568 .

70. Id.

71. Id. The Court expressly narrowed Borak and Cort to the extent they suggested that a private remedy could be inplied to further the remedial purposes of a statute even though such remedy was not intended by Congress. See note 7 and accompanying text supra.

72. 442 U.S. at 578.

73. 444 U.S. 11 (1979). 
serted" and not "the desirability of implying private rights of action in order to provide remedies thought to effectuate the purposes of a given statute."74 Simce the statutory scheine at issue ${ }^{75}$ did not indicate a congressional mtent to create a private daunage reunedy, the Court held that none could be implied. ${ }^{76}$

Under the rationale of Touche Ross and Transamerica, Kardon was wrongly decided. The implication of a private right of action under section 10(b) is not authorized by the language of that section, nor suggested by the structure of the securities acts of the legislative history of section $10(\mathrm{~b})$. Moreover, the existence of an express private right of action in other sections of the securities acts, ${ }^{77}$ but not in section 10(b), strongly suggests that Congress did not intend that one exist to redress a violation of section $10(\mathrm{~b})$. Since there is no evidence to suggest that Congress intended to create a private reunedy under section 10(b), Touche Ross and Transamerica mdicate that none should have been imphed by the courts. ${ }^{78}$ Indeed, the focus on statutory language and structure in these cases as the inethod for determining congressional imtent suggests that only im the rarest of circuunstances should courts imply a private reanedy under any provision of the securities laws where Congress has failed to create an express reinedy. ${ }^{79}$

74. Id. at $15-16$.

75. The inain question in Transamerica was whether a private damage remedy could be implied under $\S 201$ of the Investment Advisers Act of 1940, 15 U.S.C. $\$ \S 80 \mathrm{~b}-1$ - $80 \mathrm{~b}-21$ (1976).

76. The Court did hold, however, that $\$ 215$ of the Act, which provides that contracts in violation of the Act "shall be void," allows injured persons to bring an equitable action to void an investment adviser's contract in violation of the statute. 444 U.S. at 18-19. The Court also reaffirmed that the analogous $\S 29$ (b) of the 1934 Act, 15 U.S.C. $\S 78 \mathrm{cc}($ b) $(1976)$, confers a right to rescind a contract void under the criteria of that statute. $I d$.

77. Securities Act of $1933 \S \S 11,12,15$ U.S.C. $\$ \S 77 k, 77 /(1976)$; Securities Exchange Act of $1934 \S \S 9(\mathrm{e}), 16(\mathrm{~b}), 18(\mathrm{a}), 15$ U.S.C. $\$ \S 78 \mathrm{i}(\mathrm{e}), 78 \mathrm{p}(\mathrm{b}), 78 \mathrm{r}(1976)$.

78. For an excellent exposition of the view that Cengress did not intend to create a private remedy, see Ruder, Civil Liability Under Rule 10b.5: Judicial Revision of Legislative Intent?, 57 Nw. U.L. REv. 627 (1963). The Court, however, appears to be unwilling to repudiate the wellsettled case law holding that there is an imphed private remedy under $\S 10(\mathrm{~b})$ and rule $10 \mathrm{~b}-5$. See note 66 supra.

79. In a major recent decision, however, a divided Second Circuit, in an opinion writtcn by Judge Friendly, has held that there is an implied damage remedy under the Commodity Exchange Act, 7 U.S.C. $\$ \S 1-24$, (1976 \& Supp. III 1979). Leist v. Simplot, Nos. 79-7402, 79-7464, 79-7482 (2d Cir. July 8, 1980) (slip op.). The court did not, however, embrace either the tort law rationale of Kardon or the enforcement rationale of Borak as a basis for implying a private remedy. On the contrary, the court recognized that recent Supreme Court decisions make clear that "the ultimate touchstone is congressional intent and not judicial notions of what would constitute wise policy." Leist v. Simplot, Nos. 79-7402, 79-7464, 79-7482 (2d Cir. July 8, 1980), slip op. at 4092. The court reasoned that since Congress knew of the line of cases implying a private remedy umder the Commodities Exchange Act when the Act was extensively amended in 1974 and did nothing to alter the status quo, Congress must have intended that a private remedy exist. Id. at 4080-88, 4095.

Judge Mansfield dissented. In his view, the failure of the legislative history to demonstrate that Congress affirmatively approved of these cases, as opposed merely to being aware of them, precluded the implication of a private damage remedy. Id. at 4109-11. (Mansfield, J., dissenting). 


\section{Current Validity of the Use of Tort and Criminal Law as the Basis for Imposing Secondary Liability}

The tort law rationale of Kardon has been expressly followed by courts imposing secondary liability based upon tort law principles. ${ }^{80}$ However, if the dispositive question in determining whether to imply a private remedy is whether Congress intended to create such a remedy, regardless of tort law principles, congressional intent must be equally dispositive in the secondary liability context.

In fact, the case for focusing solely upon congressional intent in analyzing secondary liability, and not upon tort law or any other cominon law doctrine, is even more compelling than in the implied remedies context. Implying a private remedy to redress violations of a statute requires recognition of a cause of action even though none has been expressly created by Congress. The conduct of the defendant, however, has been expressly prohibited by Congress. The question of secondary liability, in contrast, involves expanding the scope of prohibited conduct under a statute. If tort law cannot provide a basis for implying a remedy, it necessarily follows that it cannot, without more, be used to redefine the scope of conduct prohibited by a statute. ${ }^{81}$ The

Judge Mansfield also emphasized the complex remedial structure, which includes reparations provisions, to buttress his argument that Congress did not intend to create a private remedy. Id. at 4109 (Mansfield, J., dissenting).

Both the majority and dissenting opinions, therefore, focus on congressional intent. The dissenting opinion, however, is inore consistent with Touche Ross and Transamerica. These cases hold that a court may imply a private remedy only if there is affirmative evidence that Congress intended that such a remedy exist. See Cannon v. Umversity of Chicago, 441 U.S. 667 (1979). No such evidence was cited in Judge Friendly's majority opinion. Moreover, the complex remedial provisions of the Act demonstrate that Congress was sensitive to the need for protecting investors but nevertheless failed to enact an express remedy. Even if the majority opinion, which purports to rely on congressional intent, is correct, however, it lends no support to the concept of secondary liability which is not based upon congressional intent but rather upon various common law doctrines.

The Sixth Circuit has also recently held that there is an implied damage remedy under the Commodity Exchange Act. Curran v. Merrill Lynch, Pierce, Feuner \& Smith, Inc., 622 F.2d 216 (6th Cir. 1980). Some district courts, however, have reached the opposite conclusion. E.g., Gonzales v. Paine, Webber, Jackson \& Curtis, Inc., 493 F. Supp. 499 (S.D.N.Y. 1980); Fischer v. Rosenthal \& Co., 481 F. Supp. 53 (N.D. Tex. 1979).

80. See, e.g., Breıman v. Midwestern United Life Ins. Co., 259 F. Supp. 673 (N.D. Ind. 1966), affd, 417 F.2d 147 (7th Cir. 1969), cert. denied, 397 U.S. 989 (1970).

81. Tort law, or other common law doctrines, can be rehed upon to define the scope of prohibited conduct under a statute if it appears from the language, structure, and legislative history that the statutory prohibition is coextensive with a prohibition at common law. If, for example, $\S 10(b)$ expressly prohibited aiding and abetting a violation by another defendant, the scope of aiding and abettimg hability at common law would be relevant in determining the scope of liability under the statute. See, e.g., SEC v. Capital Gains Bureau, 375 U.S. 180, 192-95 (1963) (common law of fraud supportive of language and legislative history of antifraud statute). The Court has also occasionally referred to the common law where "neither the legislative history nor the statute itself affords specific guidance." Chiarella v. United States, 445 U.S. 222, 226 (1979). There the Court relied heavily upon the scope of the duty to disclose at common law to define 
scope of such prohibited conduct must be determined solely by reference to congressional intent.

\section{III \\ SECONDARY Liability AND CONGRESSIONAL INTENT}

Since courts have uniformly rehed upon common law doctrines $\mathrm{m}$ imposing secondary liability, no attempt has been made to justify secondary liability by reference to the language of section $10(\mathrm{~b})$, the statutory frainework, or relevant legislative history. Yet, it is precisely these tools of statutory construction - and not reliance upon common law doctrines-which the Supreme Court has repeatedly utilized to restrict the substantive scope of section $10(b)$, as well as to limit the situations in which a private right of action can be judicially implied. ${ }^{82}$ The propriety of imposing secondary liability must be evaluated under this new methodology.

\section{A. The Language of the Statute}

Section $10(\mathrm{~b})$ provides that "[i]t shall be unlawful for any person, directly or indirectly ... [t]o use or employ, in connection with the purchase or sale of any security ... any manipulative or deceptive practice . . . ." It does not expressly provide that it shall also be unlawful to aid and abet, conspire with, or entploy a person who is liable under the statute. ${ }^{83}$ Under the rationale of recent Supreme Court cases,

when a failure to disclose constitutes a "manipulative or deceptive" practice within the meanimg of $\S 10(\mathrm{~b})$. Since the legislative purpose was to prevent fraud, and the failure to disclose constituted a fraud at common law only in certain circumstances, reliance on the common law in Chiarella was necessary in order to determine congressional intent as to those circumstances. Id. at 114-15. Reliance on the common law in Chiarella, therefore, was necessary to flesh out the scope of prohibited conduct under the "inanipulative or dcceptive" practice language of $\S 10(\mathrm{~b})$. It lends no support to the analysis in secondary hability cases where conduct has been prohibited under various common law doctrines without regard to whether such conduct was prohibited by the statute.

The Court has also held, however, that if the language, structure, and legislativc history of a statute demonstrate a congressional intent not to adopt the standard of liability at common law, the common law cannot be used to define the scope of prohibited conduct. See Aaron v. SEC, 100 S. Ct. 1945 (1980) (scope of prohibited conduct under antifraud sccurities defined by language, structure, and legislative history of statute, and not by the common law of fraud).

82. See cases cited in notes 7-8 supra.

83. It could conceivably be argued that the "directly or indirectly" language in \$ 10(b) might provide some statutory basis for the imposition of liabihty on aiders and abettors, conspirators, and employers of primary wrongdoers. Courts, however, have not imposed such hability on this basis but rather have rehed on various common law doctrines as the basis for secondary hability. See Part I supra.

In any event, there is no support for the proposition that Congress intended the "directly or indirectly" language to encoinpass secondary hability. The statutory scheine suggests the opposite. For instance, Congress specifically enacted $\$ 20(a)$ of the 1934 Act which cxpressly imposes hability on controlling persons. This provision would be surplusage in $\S 10(\mathrm{~b})$ cases if the "directly or indirectly" language encompassed secondary liability. This provision, and the comparable $\$ 15$ of the 1933 Act, demonstrate that when Congress intended to impose secondary liability, 
this failure of section 10 (b) or other provisions expressly to impose these forms of secondary hability is strong evidence that Congress did not intend to impose such liability upon conduct which would not otherwise be prohibited as a "manipulative or deceptive practice." 84

The Court has repeatedly emphasized that in deciding whether a complaint states a cause of action under rule $10 \mathrm{~b}-5$, it is necessary to "turn first to the language of $\S 10(\mathrm{~b})$," for " $[\mathrm{t}] \mathrm{he}$ starting point in every case involving construction of a statute is the language itself." 85 The Court has not hesitated to interpret restrictively the securities laws where the cause of action asserted was broader than the relevant statutory language.

In Blue Chip Stamps v. Manor Drug Stores, ${ }^{86}$ for example, the question was whether offerees of an allegedly misleading stock offering who never had purchased or sold any of the offering shares satisfied the "purchase or sale" requirement of section $10(b)$ and rule 10b-5. The Court emphasized that the statute prohibited manipulative or deceptive practices only "in connection with the purchase or sale of any security" ${ }^{\prime 87}$ and not in connection with any attempt to purchase or sell any security. ${ }^{88}$ The Court thus held that the plaintiff failed to state a cause of action under section $10(\mathrm{~b})$ and rule $10 \mathrm{~b}-5$.

The statutory language of section 10(b) was also held to be controlling in Ernst \& Ernst v. Hochfelder. ${ }^{89}$ There the question was whether a defendant who was only alleged to be negligent could be civilly liable for employmg a "manipulative or deceptive device or contrivance" as required by the language of section 10(b). The Court held that a defendant who was only negligent could not be liable because

it did so expressly. In light of this statutory scheme, the "directly or indirectly" language cannot be interpreted to encompass secondary liability.

One plausible interpretation of the "direct or indirectly" language is that it allows liability to be imposed upon a defendant even though such defendant does not himself use the jurisdictional means (i.e., mail a letter in interstate commerce). See 5 A. JacoBs, The IMPACT of Rule 10b-5 $\$ 3.02(f)$ n.33 (rev. ed. 1980).

84. For an analysis of which forms of secondary liability constitute "manipulative or deceptive" practices, see Part IV infra.

Although the language of rule $10 \mathrm{~b}-5$ is somewhat broader than the language of $\$ 10(\mathrm{~b}), \mathrm{com}$. pare note 1 with note 2 supra, the Court has made it clear that the language of $\$ 10(b)$ is controlling because the scope of an administrative rule promulgated by the Securities and Exchange Commission cannot be broader than the scope of the statute upon which it is based. Santa Fe Indus., Inc. v. Green, 430 U.S. 462, $472-73$ (1977); Ernst \& Emst v. Hochfelder, 425 U.S. 185, 213 14 (1976).

85. Ernst \& Ernst v. Hochfelder, 425 U.S. 185, 197 (1976). See also Santa Fe Indus., Inc. v. Green, 430 U.S. 462, 472 (1977); Blue Chip Stamps v. Manor Drug Stores, 421 U.S. 723, 756 (1975) (Powell, J, concurring).

86. 421 U.S. 723 (1975).

87. Id. at 732 .

88. Id. at 756 (Powell, J., concurring).

89. 425 U.S. 185 (1976). 
the words "manipulative," "device," and "contrivance" "make unmistakeable a congressional intent to proscribe a type of conduct quite different from negligence." 90 To impose liability for negligence, therefore, would "add a gloss to the operative language of the statute quite different from its commonly accepted meaning."91

This same emphasis on the statutory language is also evident in Santa Fe Industries, Inc. v. Green ${ }^{92}$ Plaintiff in that case alleged that a merger which resulted in elimination of mmority shareholders violated section $10(b)$ and rule $10 \mathrm{~b}-5$ even though full disclosure was made. The Court, following the analysis in Hochfelder, held that no cause of action was stated because "[t] the language of $\S 10(\mathrm{~b})$ gives no indication that Congress meant to prohibit any conduct not involving manipulation or deception." "93 Thus, in Blue Chip, Hochfelder and Santa Fe, the Supreme Court rejected section 10(b) and rule 10b-5 claims because the conduct attacked was not prohibited by the statute. This same principle is applicable with respect to secondary liability. Not only has Congress failed expressly to prohibit aiding and abetting, conspiracy, or employing a wrongdoer, but the statutory language, as interpreted by the Suprene Court, suggests that no such prohibitions were intended. Thus, the imposition of strict liability on employers under a respondeat superior theory is flatly inconsistent with the holding of Hochfelder that the "mranipulative or deceptive" language in section 10(b) requires proof of scienter as a prerequisite for liability. Similarly, the imposition of aiding and abetting or conspiracy liability on defendants who themselves do not engage in any deceptive conduct is inconsistent with the holding of Santa Fe that section 10(b) prohibits only such deceptive conduct. ${ }^{94}$

\section{B. The Statutory Framework}

Congress has expressly imposed secondary liability in several provisions of the securities laws, but not in section 10(b). Both section 15 of the 1933 Act and section 20(a) of the 1934 Act impose liability on

90. Id. at 199.

91. Id. Lower courts after Hochfelder, however, have continued to assume that aiding and abetting a violation by another defendant is prohibited by $\S 10(b)$ and rule $10 b-5$. E.g., IIT v. Cornfeld, 619 F.2d 909 (2d Cir. 1980); Edward J. Mawod \& Co. v. SEC, 591 F.2d 588 (10th Cir. 1979); Monsen v. Consolidated Dressed Beef Co., 579 F.2d 793 (3d Cir. 1978), cert. dented, 439 U.S. 930 (1979); Rolf v. Blyth, Eastman Dillon \& Co., 570 F.2d 38 (2d Cir.), cert. denied, 439 U.S. 1039 (1978). The debate has focused only on how the scienter requirement established in Hochfelder should be applied in aiding and abetting cases. Compare the majority and dissenting opinions in Rolf.

92. 430 U.S. 462 (1977).

93. Id. at 473.

94. For an analysis of which forms of secondary liability involve deceptive conduct, see Part IV infra. 
"controlling persons" provided they do not act in good faith. ${ }^{95}$ Moreover, other provisions of the 1934 Act also deal with secondary liability. Section 15(b)(4)(E), ${ }^{96}$ for exainple, gives the Commission the power to censure or place otlier limitations on any person associated with a broker-dealer for willfully aiding and abetting or otherwise inducing a securities violation by another defendant. ${ }^{97}$

Under the reasoning in Blue Chip and Hochfelder, Congress provision of secondary hability in soine sections of the securities laws but not in section $10(\mathrm{~b})$ is highly significant. In Blue Chip, the question was whether a plaintiff who had never actually purchased or sold securities could fall within the "purchase or sale" requirements of section 10(b). The Court supported its holding that such a plaintiff could not bring an action under section 10 (b) by reference to the language in other provisions of the securities laws which does address fraud "in the offer or sale" of securities. ${ }^{98}$ "When Congress wished to provide a remedy to those who neitler purchase nor sell securities," the Court concluded, "it had little trouble in doing so expressly." 99

The Court in Hochfelder similarly relied upon various provisions of the federal securities laws in rejecting the Securities and Exchange Commission's arguinent that neghigence should suffice for civil hability because section $10(\mathrm{~b})$ is not explicitly limited to willful conduct. The Court einphasized that the express recognition of causes of action preinised on negligent conduct in other provisions of the Acts "stands in sharp contrast to the language of section $10(b)$ " and, therefore, "significantly undercuts" the Commission's argunient that such conduct is prohibited by the second. ${ }^{100}$

The rationale of Blue Chip and Hochfelder is directly applicable in the secondary liability context. The express imposition of secondary liability in the controlling persons sections and in other securities statutes deinonstrates that wlien Congress intended to impose such liability, "it had little trouble in doing so expressly." Moreover, when Congress did impose such liability, it only did so under certain conditions. A defendant cannot be liable under the controlling persons provisions if lie acted in good faith. However, the imposition of respondeat superior liability under section 10(b), such as in Marbury, ${ }^{101}$ deprives controlling persons who are not acting as principals of

95. See note 37 supra.

96. 15 U.S.C. $\$ 780(b)(4)(E)$ (1976).

97. The 1934 Act also imposes duties of supervision on various entities. E.g., § 6, 15 U.S.C. $\S 78 \mathrm{f}$ (1976) (exchanges); § 17A(b)(3), 15 U.S.C. § 78q (1976) (clearing agencies).

98. 421 U.S. at 733-36.

99. Id. at 734 .

100. 425 U.S. at 208.

101. 629 F.2d 705 (2d Cir. 1980); see text accompanying notes $42-45$ supra. 
this good faith defense, and thereby disrupts the statutory scheme cstablished by Congress.

\section{Legislative History}

Where the language of a statute is sufficiently clear-and the failure of Congress expressly to prohibit aiding and abetting, conspiring with, or employing a primary violator when contrasted with the controlling person restrictions could not be clearer-such language is dispositive without resort to legislative history. ${ }^{102}$ Even if legislative history were relevant, however, there is no evidence in the legislative history of section 10(b) that Congress ever intended to prohibit aiding and abetting or conspiring with a primary violator. ${ }^{103}$ With respect to respondeat superior liability, Congress specifically chose not to impose such liability on employers.

As originally promulgated, section 15 of the 1933 Act imposed strict liability on controlling persons without regard to whether such control was exercised to bring about the securities violation. ${ }^{104}$ After strong opposition from the business community, ${ }^{105}$ however, Congress decided to "liberalize" the provision. ${ }^{106}$ Section 15 was amended to provide that a controlling person would be liable "unless the controlling person had no knowledge of or reasonable ground to believe in the existence of the facts by reason of which the liability of the controlled

102. Santa Fe Indus., Inc. v. Green, 430 U.S. 462, 477 (1977); Ernst \& Ernst v. Hochfelder, 425 U.S. at 201.

103. Congress has, however, specifically rejected several attempts to amend the securities laws expressly to prohibit aiding and abetting a violation of $\$ 10(\mathrm{~b})$. H.R. 5001 and S. 1178, 86th Cong., 1st Sess. (1959) would have inade it unlawful "for any person to aid, abet, counsel, command, induce or procure the violation of any provision of [the 1933 Act]." Securities Acts Amendments, 1959, Hearings on H.R. 5001 Before a Subcomm. of the House Comm. on Interstate and Foreign Commerce, 86th Cong., 1st Sess. 89, 103 (1959). Because of industry fears that the amendment might have resulted in aiders and abettors being hable for dainages, the Securities and Exchange Commission agreed that the bill should be clarified to indicate that "no civil liability is intended." SEC Legislation: Hearings on S. 1178-1182 Before a Subcomm. of the Senate Comm. on Banking and Currency, 86th Cong., 1st Sess. 288 (1959). Language subjecting aiders and abettors to injunctions was reintroduced in 1960 as S. 3770 . None of these bills was ever enacted.

104. H.R. ReP. No. 152, 73d Cong., 1st Sess. 26 (1933).

105. The original version of $\S 15$ raised numerous complaints from the business community, which felt it was "too drastic, and interfered with business." 78 CoNG. REC. 8668 (1934) (remarks of Senator Fletcher).

106. Id. The intent of the proposed amendinent to $\$ 15$ was "to restrict the scope of the section so as more accurately to carry out its real purpose." Id. at 8669 (1934) (Menorandum Explanatory of Suggested Amendments to the Securities Act). See also id. at 10260, 10265 (1934) (Statement of House Conferees). Accordingly, "[t]he inere existence of control [was] not inade a basis for hability if it is shown that the controlling person had no knowledge of or reasonable ground to beheve in the existence of the facts upon which the liability of the controlled person [was] alleged to [have been] based." Id. 
person is alleged to exist."107 By enacting this version of section 15, Congress rejected the earlier strict hability version. Since the subsequently enacted version of section 20 of the 1934 Act similarly contains a good faith defense, ${ }^{108}$ it also constitutes a rejection of the strict hability standard.

Those courts which have held einployers strictly liable under a respondeat superior theory as a inatter of federal law, therefore, have acted contrary to the legislative intent of Congress. Since such a result is inconsistent with the most basic canons of statutory construction, it necessarily follows that employers should be liable under the federal securities laws for the acts of their employees only if they fall within the statutory definition of a controlling person who does not act in good faith as provided in sections 15 and 20.

\section{The Case of SEC Enforcement Actions}

To enjoin a violation of section $10(\mathrm{~b})$ in an enforcement proceeding, the Commission, like a private litigant, must establish that the defendant engaged in a "inanipulative or deceptive" practice. ${ }^{109}$ Since the language of section $10(\mathrm{~b})$, the statutory structure, and the relevant legislative history do not indicate any congressional intent to impose secondary liability, there should be no difference between an SEC enforceinent action and an imphed private right of action for damages. Secondary liability should not be recognized in either type of action.

The analysis is made somewhat more complicated, however, by a provision in the Criminal Code ${ }^{110}$ which provides that any person who aids and abets or otherwise assists in the commission of a crime against the United States is punishable as a principal. A person who aids and abets in the commission of a securities violation, therefore, can be criminally liable under this provision because a violation of a securities statute is an offense against the United States. Based upon this provision in the Criminal Code at least one court has held that because of the similarity between an SEC enforceinent proceeding and a criminal action, "no good reason" exists why the SEC should not be able to enjoin the aiding and abetting of a securities violation. ${ }^{11}$

107. 15 U.S.C. $\$ 770$ (1976), as amended by Act of June 6, 1934, Pub. L. No. 93-291, § 208, 48 Stat. 908.

108. See note 37 supra.

109. The Supreme Court has tended not to distinguish between private damage actions and SEC enforcement proceedings in interpreting the "manipulative or deceptive" practice language. See Aaron v. SEC, 100 S. Ct. 1945 (1980) (scienter required in both private damage actions and SEC injunctive actions).

110. 18 U.S.C. $\$ 2$ (1976).

111. In SEC v. Timetrust, Inc., 28 F. Supp. 34 (N.D. Cal. 1939), a Commission enforcement proceeding, the court relied upon 18 U.S.C. $\$ 2$ (1976), which provides that whoever aids and 
While the analogy between a criminal prosecution and an SEC enforcement proceeding has a certain superficial appeal, ${ }^{112}$ it ultimately is not persuasive. The existence of criminal prohibitions against a form of conduct does not necessarily mean that there should be civil prohibitions under a different federal statute for the same conduct. The ultimate question is whether Congress intended that there be such civil prohibitions.

Congress is perfectly free to decide, for example, that because both an SEC enforcement proceeding and a criminal prosecution are brought by the government to serve the public imterest, aiding and abetting should be actionable under both types of actions. There is no evidence, however, that Congress has made such a decision. When Congress intended to provide the SEC with power to regulate aiding and abetting, it did so expressly. Thus, section 15(b)(4)(E) of the 1934 Act $^{113}$ as amended expressly authorizes the Commission to censure any broker or dealer, or any person associated with a broker or dealer, who "has willfully aided, abetted, counseled, commanded, induced or procured the violation by any other person of any provision [of the securities laws]." 114 Section 21(d) of the 1934 Act, ${ }^{115}$ the section that authorizes the SEC to seek injunctive rehef, however, contams no such language. Since Congress apparently did not intend that the SEC have the power to enjom aiding and abetting under section 21 (d), such a remedy should not be implied from the existence of a criminal remedy for the same conduct under a different statute.

\section{E. The Relevance of Policy Arguments}

It could be argued that effective enforcement of the securities laws requires that liability in securities cases be imposed on peripheral de-

abets in the commission of an offense against the United States is punishable as a principal, to justify enjoining such secondary conduct. The court reasoned:

The present suit, seeking injunctive relief, sounds in fraud, and is similar in many respects to a criminal prosecution. The Criminal Code of the United States provides that whoever aids or abets in the commission of an offense is a principal. Persons charged with aiding and abetting a criminal offense in violation of Sec. 17(a) may be joined as defendants, and no good reason appears why this same rule should not apply in an injunctive proceeding to restrain a violation of the same statute.

28 F. Supp. at 43 (footnotes omitted).

112. The analogy is far from perfect. Criminal aetions involve a panoply of procedural protections, such as the right to jury trial, the right to counsel, and the right to be convicted only upon proof beyond a reasonable doubt, which are absent in an SEC enforcement proceedimg. The level of scienter necessary to hold a defendant liable under a criminal prosecution may also be significantly higher than in a civil action. Compare Nye \& Nissen v. United States, 336 U.S. 613 (1949) (scienter for criminal aiding and abetting) with Ernst \& Erust v. Hochfelder, 425 U.S. 185 (1976) (scienter necessary in civil action).

113. 15 U.S.C. $\$ 780(b)(4)(E)(1976)$.

114. Id.

115. 15 U.S.C. $\$ 780$ (d) (1976). 
fendants who provide some assistance to the primary wrongdoer or who are in a position to prevent the wrongdoing. Section 10 (b) and rule $10 \mathrm{~b}-5$, the argument runs, must be construed flexibly so as to implement their remedial purposes. ${ }^{116}$

The problem with this argument is that it subsumes far too much. Indeed, it is no more than a restatement of the enforcement rationale of Borak, which was narrowed in Cort $v$. Ash and expressly rejected in Touche Ross and Transamerica as a basis for implying a private right of action. ${ }^{117}$ The Court has also rejected the enforcement rationale as a basis for construmg the substantive scope of the securities laws more broadly than their language and structure would reasonably permit. As the Court stated in Aaron v. SEC,

"[G]eneralized references to the 'remedial purposes" " of the securities laws "will not justify readimg a provision "more broadly than its language and the statutory scheme reasonably permit'.". . Thus, if the language of a provision of the securities laws is sufficiently clear in its context and not at odds with the legislative history, it is unnecessary "to examine the additional considerations of 'policy' ... that may have influenced the lawmakers in their formulation of the statute."118

In any event, the relevant policy arguments do not all point im one direction. For one thing, the threat of secondary liability affects defendants who are not engaged in the purchase or sale of securities. In most cases, the defendant who is alleged to be secondarily liable will merely be engaged in customary busmess activities such as lending inoney, managing a corporation, supervising employees, preparing financial statements, or giving legal advice. ${ }^{119}$ It is all too easy for a clever plaintiff's lawyer, looking for a deep pocket, to allege that imdi-

116. The district court opinion in Brennan relied on precisely this argunent in holding that a defendant could be liable for aiding and abetting even though the statutes contain no such express prohibition. Brennan v. Midwestern United Life Ins. Co., 259 F. Supp. 673, 681 (N.D. Ind. 1966). See also notes 21-28 and accoinpanying text supra.

117. As one court lias stated, the Supreine Court has "rejected any reliance upon the desirabihty of inferring a private right of action. . . " Gateway Indus., Inc. v. Agency Rent A Car, Inc., 495 F. Supp. 92, 96 (N.D. Ill. 1980).

118. $100 \mathrm{~S}$. Ct. 1945, 1955 (1980) (citations onitted).

A different case would be presented if Congress, in enacting or in reenacting the Securities Exchange Act, had been aware of a particular judicial or administrative construction which it intended to adopt. E.g., Lorillard v. Pons, 434 U.S. 575 (1978). A different case might even be presented if Congress reenacted $\S 10$ (b) of the Seeurities Exchange Act without commenting on an established judicial construction. Compare the majority and dissenting opimions in Leist v. Simplot, Nos. 79-7402, 79-7464, $79-7482$ (2d Cir. July 8, 1980). See note 79 supra. But cf. SEC v. Sloan, 436 U.S. 103 (1978) (Congress not presuned to approve longstanding administrative interpretation). In the secondary liability context, none of the above possibilities are presented because there has been no reenactment of $\$ 10$ (b) where Congress could be said to either have approved of, or even acquiesced to, the various forms of secondary liability. See note 103 and accompanying text supra.

119. See Ruder, supra note 4, at 632. 
viduals performing these functions knew or, but for their recklessness, would have known of the fraudulent conduct of the primary defendant but nevertheless lent assistance to the scheme. Even if such a claim cannot be proved at trial, it may have significant settlement value. ${ }^{120}$ In the event that the claim is meritorious, the plaimtiff would not necessarily be left without a remedy under the approach proposed in this Article, but rather would have to look to state law in order to recover.

\section{IV}

\section{The Proper Range of Liability Under Section 10(b)}

Under the analysis proposed in this Article, defendants can no longer be held liable in a civil action under section 10(b) and rule 10b-5 on aiding and abetting, conspiracy, or respondeat superior theories. Such defendants can be held hable, if at all, only if they have engaged in a "manipulative or deceptive practice" prohibited by section 10(b). ${ }^{121}$ Recent decisions make clear that in order to fall within this statutory prohibition, a defendant, acting with scienter, ${ }^{122}$ must make a inaterial misrepresentation or wrongfully fail to disclose despite a fiduciary duty to do $\mathrm{so}^{123}$ in connection with the purchase or sale of a security, or engage in a manipulative practice designed to mislead in-

120. The Supreme Court has recognized that "litigation under Rule 10b-5 presents a danger of vexatiousness different in degree and in kind from that which accompanies litigation in general" and that "even a complaint whicl by objective standards may lave very little clance of success at trial has a settleinent value to the plaintiff out of any proportion to its prospect of success at trial . . . B" Blue Chip Stamps v. Manor Drug Stores, 421 U.S. 723, 739-40 (1975).

121. It is not enough that a defeudant engages in conduct that arguably "operates as a fraud" or otherwise violates the language of rule $10 \mathrm{~b}-5$. The Supreme Court has made it clear that the scope of the rule can be no broader than the range of prohibited conduct uuder the "manipulative or deceptive" language of $\$ 10(\mathrm{~b})$. See uote 84 supra.

122. The scienter requirement was established in Ernst \& Ernst v. Hoclifelder, 425 U.S. 185 (1976), and extended to SEC imjunctive actions in Aarou v. SEC, $100 \mathrm{~S}$. Ct. 1945 (1980).

123. Santa Fe Indus., Inc. v. Green, 430 U.S. 462 (1977). A duty to disclose under the antifraud provisions has most frequently been imphed where a party trades on imside information. If a party does not trade on inside information, no duty to disclose has been imposed. The most famous exposition of the disclose-or-refrain-from-trading rule is folmd in Cady, Roberts \& Co., 40 S.E.C. 907 (1961). The disclose-or-refrain-from-trading rule, and the persons against whom that rule is applicable, are discussed in Chiarella v. Umited States, 445 U.S. 222 (1980). See also note 81 supra.

A duty to disclose to customers has also occasionally been imposed on broker-dealers in certain situations. E.g., Sutton v. Shearson Hayden Stone, Inc., 490 F. Supp. 98 (S.D.N.Y. 1980) (failure of brokerage house to disclose customer complaints actionable under $\S 10(\mathrm{~b})$ and rule 10b-5). One possible basis for this duty to disclose imposed on broker-dealers is the so-called "shingle theory." The "shingle theory" provides, in esseuce, that a broker or dealer who hangs out his shingle impliedly represents that he will deal fairly with the public. The theory can be utilized to prohibit a wide range of broker-dealer abuses including the sale of securities at a price not reasonably related to inarket value, the effecting of unauthorized transactions, or the recommendation of unsuitable investments without full disclosure. See generally L. Loss, SEcurities ReoULATION 1482-93 (2d ed. 1961). The Supreme Court has never liad occasion to consider the "shingle thcory," and the precise limits of the doctrine are unclear. 
vestors by artificially affecting inarket activity. ${ }^{124}$

The abohtion of secondary liability will not make all cases easy to decide. Frequently the line between primary and secondary liability is blurred, and the resolution of the question of whether a peripheral defendant in a securities case has violated the express prohibition of a statute will be difficult. Nevertheless, it is possible to make some general observations on the potential liability of groups of defendants who have traditionally been lield hable on aiding and abetting, conspiracy, or respondeat superior theories.

\section{A. Defendants Who Fail to "Blow the Whistle" on Primary Wrongdoers}

Defendants who fail to report or disclose primary violations cominitted by others have been held to have acted as aiders and abettors. ${ }^{125}$ This "whistle blowing" theory of liability does not survive the abolition of secondary liability proposed in this Article.

The first suggestion that the failure to report fraud to regulatory authorities could constitute aiding and abetting is found in the original district court opinion in Brennan v. Midwestern United Life Insurance Co. ${ }^{126}$ There plaintiff claimed that defendant, a life insurance company, was hable under the federal securities laws for aiding and abetting a rule $10 \mathrm{~b}-5$ violation by a brokerage firm in connection with the sale of shares of the defendant life insurance company's stock. The insurance coinpany itself was not accused of engaging in manipulative or deceptive practices. Rather, the conplaint alleged that it was liable as an aider and abettor because it knew of the fraud being committed by the brokerage firm but failed to report it to the state securities commission or to the Securities Exchange Commission. Based on these allegations, the defendant's motion to disnniss for failure to state a claim was denied, and it was eventually held liable as an aider and abettor. ${ }^{127}$

124. The Court has stated that the prohibition against "manipulative" practices in $\$ 10(\mathrm{~b})$ is "virtually a term of art" which "refers generally to practices, such as wash sales, matched orders, or rigged prices, that are intended to mislead investors by artificially affecting market activity." Santa Fe Indus., Inc. v. Green, 430 U.S. 462, 476 (1977). See also Emst \& Ernst v. Hochfelder, 425 U.S. 185,199 (1976).

125. E.g., SEC v. National Student Marketing Corp., 457 F. Supp. 682 (D.D.C. 1978); Brennan v. Midwestern United Life Ins. Co., 259 F. Supp. 673 (N.D. Ind. 1966) (motion to dismiss), 286 F. Supp. 702 (N.D. Ind. 1968) (after trial), aff'd, 417 F.2d 148 (7th Cir. 1969), cert. denied, 397 U.S. 989 (1970).

126. 259 F. Supp. 673 (N.D. Ind. 1966).

127. While the court of appeals affirmed the district court in Brennan, it refused to decide whether the failure to report the fraud to regulatory authorities was sufficient to impose aiding and abetting habihty. 417 F.2d at 155 . The court stated that Midwestern also engaged in "affirmative acts" to further the fraud, and these acts, coupled with the failure to report the fraud, were sufficient for aiding and abetting hability. Id. at 154. The "affirmative acts" by Midwestern relied upon by the court, however, consisted of referring complaints by stockholders to the broker and 
The Securities and Exchange Commission in recent years has also attempted to expand greatly the duty of accountants and lawyers to disclose fraud to the investing public and to report fraud to the Commission. ${ }^{128}$ In its well-known complaint in the National Student Marketing case, ${ }^{129}$ for example, the Securities and Exchange Commission alleged that accountants and lawyers acted as aiders and abettors under section $10(\mathrm{~b})$ because they failed to take adequate steps to disclose a securities fraud to various parties in a inerger transaction. The accountants and lawyers were also alleged to have acted as aiders and abettors for failing to report the fraud to the Commission. While the district court did not endorse this extreme view, ${ }^{130}$ it did hold that the lawyers aided and abetted the fraud ${ }^{131}$ because they failed to inform their own client at the closing that the merger could not go forward until certain financial information was disclosed and approved by shareholders. ${ }^{132}$ The court did not decide whether a lawyer or an accountant who has knowledge of an imminent fraud has a duty to disclose the existence of such fraud to the Commission.

If aiding and abetting is no longer a viable theory, however, the question becoines whether the lawyers in National Student Marketing or the imsurance company in Brennan engaged in a "manipulative or deceptive practice." Failure to disclose has generally been held to constitute a prohibited "manipulative or deceptive practice" only where a defendant trades on confidential inside information without disclosure to the opposing party to the transaction. ${ }^{133}$ Neither National Student Marketing nor Brennan mvolved trading or the failure to disclose to an

writing a letter to the broker informing him that unless certain action were taken, the matter would be referred to the Indiana Securities Commission. Id. at I52-53. Given the insignificant nature of these "affirmative acts," the Court of Appeals opimion is in effect an endorseinent of the district court that the failure to report by itself could justify aiding and abetting liability. For cases interpreting Brennan as an "maction" case, see, e.g., IIT v. Cornfeld, 619 F.2d 909, 926-27 (2d Cir. 1980); Rochez Bros., Inc. v. Rhoades, 527 F.2d 880, 889 (3d Cir. 1975); Woodward v. Metro Bank of Dallas, 522 F.2d 84, 96 (5th Cir. 1975); SEC v. Coffey, 493 F.2d 1304, 1317 (6th Cir. 1974), cerl. denied, 420 U.S. 908 (1975).

128. See, e.g., Garrett, New Directions in Professional Responsibility, 29 Bus. LAw. 7 (Special Issue 1974); Sonde, The Responsibility of Professionals Under the Federal Securities Laws-Some Observations, 68 Nw. U.L. Rev. 1 (1973).

I29. SEC v. National Student Marketing Corp., [1971-1972 Transfer Binder] Fed. SEC. L. REP. (CCH) If 93,360 at $91,913-17$ (D.D.C. 1972).

I30. The court stated that failure to report the fraud until after the unerger was consummated did not substantially assist the merger and therefore could not constitute aiding and abetting. 457 F. Supp. at $712-14$.

I31. The case against the accountant defendants was settled by consent decree prior to trial. Id. at 686-87 \& nn.1-2.

132. Id. at 713. It is unclear whether the court would have further required the lawyer defendants to disclose their knowledge of the fraud to the Commission or make other disclosures if they had disclosed the informatiou to their chient, and the client chose to ignore it. Cf. note 127 supra (issuer's failure to report fraud).

133. See note 123 supra. 
opposing party. Rather, these cases involved the failure to disclose to one's own client and/or to regulatory authorities. This failure to disclose fraud committed by others, whether or not unethical or in breach of some other professional obligation, ${ }^{134}$ simply does not constitute a securities violation because there has been no abuse of inside information or other failure to disclose despite a fiduciary duty to do so.

\section{B. Liability for Providing Substantial Assistance Despite Knowledge of Fraud}

Defendants, such as banks, that know of the existence of a fraud but nevertheless provide substantial assistance toward its consummation, liave been held liable as aiders and abettors under section $10(\mathrm{~b}){ }^{135}$ The recent Third Circuit case of Monsen v. Consolidated Dressed Beef Co. ${ }^{136}$ is a good example of this trend.

In Monsen, Consolidated issued unsecured promissory notes to its employees, which violated the registration and antifraud provisions of the federal securities laws. First Peımsylvania Bank was also alleged to have violated section $10(\mathrm{~b})$ and rule 10b-5 because of its role in the illegal scheme. The bank was found to have known about the underlymg securities violation but nevertheless demanded subordination of the notes to its own secured loan and otherwise encouraged continuation of the program. The Third Circuit held that the bank's knowledge of the illegal note program, coupled with its insistence on the continuation and subordmation of the notes, satisfied the traditional requirements of aiding and abettimg - knowledge of the underlying violation and substantial assistance-and, therefore, held the bank liable under section 10 (b) and rule $10 \mathrm{~b}-5 .{ }^{137}$

Monsen is illustrative of the general rule that banks will be held liable under the section and the rule for aiding and abettimg an offense committed by a primary wrongdoer. The proper question, however, is

134. On the relationship between the duty to disclose fraud and the traditional attorney-client relationship, see Comment, Securities Law-Attorney's Liability-Aiding and Abetting-SEC v National Student Marketing Corp., 25 N.Y.L. REv. 79, 95-100 (1979), and authorities cited therein.

135. See note 15 supra.

136. 579 F.2d 793 (3d Cir. 1978), cert. denied, 439 U.S. 930 (1979).

137. There is some evidence that the Third Circuit may be clianging its position. In Collins v. Signetics Corp., 605 F.2d 110 (3d Cir. 1979), the court recognized the Supreme Court's emphasis on statutory language and held that the language of $\S 12(2)$ of the Securities Act of 1933, 15 U.S.C. $\$ 771(2)$ (1976), forbidding fraud in the "offer or sale" of a security (see note 128 infra), must be construed literally. Thus, the absence of a special relationship between the issuer and the actual seller, which would liave created privity between the plaintiff purchaser and the defendant issuer, was held to preclude recovery under $\$ 12(2)$. Although the court attempted to distinguisl Monsen, primarily on the ground that no claim of aiding and abetting liability was before it, 605 F.2d at 113-14, the literal approach of the court in Signetics is inconsistent with the complete absence in Monsen of any attempt to reconcile liability with the statutory language. 
not whether the conduct of a bank-defendant satisfied the requirement of the common law doctrines of aiding and abetting or conspiracy, but whether the bank engaged in a "manipulative or deceptive" practice within the neaning of section $10(\mathrm{~b})$ as those terms have been imterpreted by the Suprenie Court. If a bank (such as the bank-defendant im Monsen) has not engaged in any deception, Santa Fe compels the conclusion that it has not engaged in any conduct prohibited under section 10(b). It is only by improperly analyzing the question of liability by reference to various cominon law doctrimes that courts, such as the Third Circuit in Monsen, have avoided this conclusion. Once the scope of hability is determined by the language, structure, and history of the statute, however, it necessarily follows that banks will not be liable under section 10(b) unless they engage in some form of deceptive conduct. 138

\section{Liability for Employing or Failing to Supervise Primary Wrongdoers}

Courts have frequently held that various types of defendants can be liable under section 10 (b) and rule 10b-5 for einploying or failing to supervise primary wrongdoers on either an aiding and abetting or a respondeat superior theory. ${ }^{139}$ In $S E C$ v. First Securities Co., ${ }^{140}$ for exainple, a brokerage firm was held liable for aiding and abetting under the section and the rule because it allowed the wrongdoer to become president of the firm and otherwise allowed the fraud to occur. Similarly, in Marbury Management, Inc. v. Kohn, ${ }^{141}$ the Second Circuit held that a brokerage firm can be strictly liable under a respondeat superior theory for einploying an individual who commits a securities fraud within the scope of his employment.

The imposition of liability for einploying and/or failing to supervise a primary wrongdoer has not been limited to broker-dealers. In Aaron v. $S E C,{ }^{142}$ for example, the Second Circuit held that a inanagerial einployee charged with the supervision of sales by registered representatives was an aider and abettor because he failed to supervise and otherwise prevent fraudulent practices froin continuing. In Pettit $v$.

138. It could be argued that a bank which knowingly lent substantial assistance to a fraudulent scheme, but did not itself engage in a inanipulative or deceptive practice, was nevertheless liable as a "participant." For a criticism of the concept of participation liability, see notes 155-62 and accompanying text infra.

139. E.g., Marbury Mgmt., Inc. v. Kohn 629 F.2d 705 (2d Cir. 1980); SEC v. First Sec. Co., 463 F.2d 981 (7th Cir. 1972); Buttrey v. Merrill Lynch, Pierce, Fenner \& Smith, Inc., 410 F.2d 135 (7th Cir. 1969); Pettit v. American Stock Exch., 217 F. Supp. 21 (S.D.N.Y. 1963).

140. 463 F.2d 981 (7th Cir. 1972).

141. 629 F.2d 705 (2d Cir. 1980).

142. 605 F.2d 612 (2d Cir. 1979), vacated and remanded, 100 S. Ct. 1945 (1980). 
American Stock Exchange, ${ }^{143}$ the court held that a stock exchange could be liable for aiding and abetting a fraud "by failing to take necessary disciplinary action" against some of its brokers who it knew or should have known were engaged in fraudulent practices.

When these forms of conduct are analyzed in terms of the "manipulative or deceptive" language of section 10(b), however, a far different picture emerges. A managerial employee who fails to supervise his sales representatives adequately, even if he has reason to suspect wrongdoing, has not himself engaged im any deceptive conduct in the form of misrepresentations or tradimg on imside information without disclosure and, therefore, has not engaged in any conduct prohibited by section 10(b). A stock exchange that fails to police its inember firms properly similarly has committed no manipulative or deceptive practice as those terms have been defined by the Supreme Court. ${ }^{144} \mathrm{~A}$ brokerdealer that does no more than employ an individual who engages in prohibited conduct also has not itself engaged in a nanipulative or deceptive practice and certainly has not acted with scienter as required by Hochfelder. Only if these defendants are "controlling persons" under Section 20(a) should they be liable under section 10(b) and rule $10 \mathrm{~b}-5 .{ }^{145}$

\section{Liability for the Transmission of Inaccurate Information}

Section $10(\mathrm{~b})$ and rule $10 \mathrm{~b}-5$ prohibit the dissemination or transmission of materially inaccurate information to mvestors im counection with the purchase or sale of a security, provided the defendant acts with scienter. The question is whether this prohibition should extend to parties who are not the central actors in a fraudulent securities scheine.

Liability under the section and the rule has been imposed on accountants, for example, for knowingly preparimg or certifying false and misleading financial statements. ${ }^{146}$ Courts have recognized that an accountant's act of certification is tantamount to a representation made by a purchaser or seller of securities, since both acts are justifiably relied upon by mvestors. ${ }^{147}$ Thus, in Herzfeld v. Laventhol, Krekstein,

143. 217 F. Supp. 21 (S.D.N.Y. 1963).

144. However, the stock exchange might violate $\S 6$ of the 1934 Act, 15 U.S.C. $\S 78 \mathrm{f}$ (1975), which requires that it adequately supervise its members.

145. A different situation is presented, however, in the case of a broker-dealer firm which employs an agent who engages in a securities scheme which is known to its board cf directors. Since a firm can act only through its agents, the firm in the above hypothetical would be liable under the federal securities laws. The scienter requirement is satisfied by the knowledge of the board of director which is imputed to the firm. The resulting liability, however, is for a direct violation of the statute, not for a violation based on a respondeat superior theory.

146. E.g., Herzfeld v. Laventhol, Krekstein, Horwath \& Horwath, 540 F.2d 27 (2d Cir. 1976); McLean v. Alexander, 420 F. Supp. 1057 (D. Del. 1976).

147. Fischer v. Kletz, 266 F. Supp. 180, 186 (S.D.N.Y. 1967). 
Horwath \& Horwath ${ }^{148}$ an accounting firm was held hable under rule $10 \mathrm{~b}-5$ because of its knowing participation in the preparation and issuance of false and materially misleading accounting reports that an investor relied upon to his detriment. In Fischer v. Kletz, ${ }^{149}$ the court went further and held that an accountant has a duty under some circumstances to disclose to the public that its previously certified financial report was false and misleading.

Attorneys, who also play a crucial role in the information transmission process, lave similarly been penalized for inaking false statements. In botl $S E C$ v. Spectrum, Ltd. ${ }^{150}$ and $S E C$ v. Covcn, ${ }^{151}$ for example, the Second Circuit held that attorneys who prepared false opmion letters which furtlered an illegal securities scheine were aiders and abettors.

Deceptive conduct by attorneys and accountants, whether previously analyzed as aiding and abetting or as a direct violation, should contimue to be prohibited by the section and the rule, provided the otler elements of liability, such as scienter 152 and the "in connection with" requirement ${ }^{153}$ are satisfied. ${ }^{154}$ Unlike the other forms of conduct discussed in preceding sections, the making of misrepresentations whicl distort the transmission of accurate information is the core conduct whicli section $10(\mathrm{~b})$ and rule $10 \mathrm{~b}-5$ are meant to deter. That such misrepresentations are made by accountants or lawyers should not provide a shield from liability.

148. 540 F.2d 27 (2d Cir. 1976).

149. 266 F. Supp. 180 (S.D.N.Y. 1967).

150. 489 F.2d 535 (2d Cir. 1973).

151. 581 F.2d 1020 (2d Cir. 1978), cert. denied, 440 U.S. 950 (1979).

152. The Supreme Court has expressly reserved the question of whether recklessness can constitute scienter. Aaron v. SEC, 100 S. Ct. 1945, 1950 n.5 (1980); Enst \& Enst v. Hochfelder, 425 U.S. 185,193 n.12 (1976). The resolution of this issue will be highly significant in cases of accountant and attorney hability because these types of defendants frequently possess no intent to defraud the plaimtiff. For example, it is highly unlikely that an accounting firm's certification of maccurate financial statements resulting from an inadequate audit is attributable to a desire to defraud investors.

153. Some cases involving alleged accountant liability have adopted extremely expansive interpretations of the "in connection witl" requirement. E.g., Competitive Assoc., Inc. v. Laventol, Krekstein, Horwath \& Horwath, 516 F.2d 811 (2d Cir. 1975) (holding that accountants who allegedly certified false and misleading financial statements of an imvestment fund managed by an investment company in order to induce plaintiff to hire the investment company which then defrauded the plaimtiff engaged in a deceptive practice in connection with the purchase or sale of a security).

154. There is some possibility that certain types of misstatenents will not be actionable under the section and the rule even if all the criteria for hability are met. In Touche Ross \& Co. v. Redington, 442 U.S. 560 (1979), the Court indicated, without deciding, that there is evidence to support the view that $\S 18$ (a) of the 1934 Act, 15 U.S.C. $\$ 78 \mathrm{r}$ (a) (1976), was intended to be the exclusive remedy for misstatements contained in any report prepared or certified by an accountant filed with the Commission. 


\section{E. A Note on Secondary Liability Under Other Provisions of the Securities Laws}

The vast majority of the secondary liability cases arise under section $10(\mathrm{~b})$ and rule $10 \mathrm{~b}-5$. Defendants have also been held secondarily liable, however, under other provisions of the securities acts. Two of these situations are discussed briefly below.

\section{Aiding and Abetting or Participating in a Violation of Section 12(2) of the $1933 \mathrm{Act}$}

Section 12(2) of the 1933 Act $^{155}$ imposes liability upon a person who makes misrepresentations in colmection with offering or selling a security. Several courts have faced the question of whether a defendant can be liable as an aider and abettor under section 12(2) even though such defendant never "offered or sold a security." 156 While some courts have imterpreted the offer or sale language strictly, ${ }^{157}$ other courts have effectively disregarded the statutory language and have held that defendants can be hable on an aiding and abetting ${ }^{158}$ or a participation theory. ${ }^{159}$

In In re Caesar's Palace Securities Litigation, ${ }^{160}$ for example, the court held that accountants could be liable under section 12(2) for misleading statements in connection with a sale of securities. Similarly,

155. 15 U.S.C. $\$ 771(2)$ (1976).

156. Section 12(2) of the 1933 Act provides in relevant part:

Any person who:-

(2) offers or sells a security . . . by means of a prospectus or oral communications, which includes an untrue statement of material fact or omits to state a material fact necessary in order to make the statements, in the light of the circumstances under which they were made, not misleading (the purchaser not knowing of such untruth or omission), and who shall not sustain the burden of proof that he did not know, and in the exercise of reasonable care could not have known, of such untruth or omission, shall be liable to the person purchasing such security from him, who may sue either at law or in equity in any court of competent jurisdiction, to recover the consideration paid for such security with interest thereon, less the amount of any income received thereon, upon the tender of such security, or for damages if he no longer owns the security.

157. E.g., Collins v. Signetics Corp., 605 F.2d 110 (3d Cir. 1979); McFarland v. Memorex Corp., 493 F. Supp. 631 (N.D. Cal. 1980); Turner v. First Wis. Mortgage Trust, 454 F. Supp. 899 (E.D.. Wis. 1978); In re Equity Funding Corp. of Am. Sec. Litigation, 416 F. Supp. 161 (C.D. Cal. 1976); duPont v. Wyly, 61 F.R.D. 615 (D. Del. 1973); Dorfman v. First Boston Corp., 336 F. Supp. 1089 (E.D. Pa. 1972).

158. E.g., Vogel v. Trahan, [1979-1980 Transfer Bimdèr] FED. SEC. L. REP. (CCH) I 97,303 (E.D. Pa. Jan. 11, 1980); In re Caesar's Palace Sec. Litigation, 360 F. Supp. 366 (S.D.N.Y. 1973).

159. E.g., Lawler v. Gilliam, 569 F.2d 1283 (4th Cir. 1978); Katz v. Amos Treat \& Co., 411 F.2d 1046 (2d Cir. 1969); Zachman v. Erwin, 186 F. Supp. 691 (S.D. Tex. 1960); Womieman v. Stratford Sec. Co., [1957-1961 Transfer Binder] FED. SEC. L. REP. (CCH) I 90,923 (S.D.N.Y. 1959). Other courts have approved the concept of participant liability if the participation is a "substantial factor in causing the transaction to take place." Croy v. Campbell, 624 F.2d 709, 714 (5th Cir. 1980); Pharo v. Smith, 621 F.2d 656 (5th Cir. 1980).

160. 360 F. Supp. 366 (S.D.N.Y. 1973). 
the court in Zachman v. Ervin ${ }^{161}$ held that members of an advisory board who participated in the fraudulent sale of a security by allowing their names to be used in the selling effort could be liable under section 12(2).

Under the analysis proposed in this Article, Caesar's Palace, Zachman, and other cases endorsing the aiding and abettimg or participation theories of liability under section 12(2) are wrongly decided. The statutory language unambiguously limits liability to a "person who offers or sells" a security. Moreover, the remedy provided in section 12(2)-rescission if the aggrieved buyer still owns the security or damages if he does not-strongly suggests that the remedy exists only against the immediate seller. Courts should impose liability, therefore, only on those in direct privity who actually "offer or sell" a security. ${ }^{162}$

\section{Aiding and Abetting a Violation of Section 17(a) of the 1934 Act}

Section 17(a) of the 1934 Act $^{163}$ requires broker-dealers to file certain financial reports with regulatory authorities. In Redington $v$. Touche Ross \& Co., ${ }^{164}$ plaintiff, a custoiner of a brokerage firm, alleged that an accounting firm was liable in damages for aiding and abetting a violation of these reporting requirements. The district court dismissed the coinplaint, ${ }^{165}$ holding that section 17 (a) imposes duties only on broker-dealers, and nowhere mentions any duties imposed upon accountants. The Second Circuit reversed, ${ }^{166}$ holding that accountants could be hable under section 17(a) and that there was an implied private right of action under the section. The Supreme Court again reversed, ${ }^{167}$ holding that there is no imphed private right of action under section 17(a). It did not reach the question of whether an accountant can be hable under section 17(a).

If, as the Supreine Court has repeatedly stated, the language of a statute is dispositive where it is sufficiently clear, ${ }^{168}$ accountants should not be hable under section 17(a) for their role in preparing reports to

161. 186 F. Supp. 691 (S.D. Tex. 1960).

162. In Collins v. Signetics Corp., 605 F.2d 110, 113 (3d Cir. 1979), the Third Circuit recognized that recent Supreme Court cases which have emphasized the importance of statutory language require that the "offer or sale" language in \$12(2) be interpreted hiterally. Thus, the absence of privity between the plaintiff purchaser and a nonseller issuer defendant was held to preclude recovery under § 12(2). See note 137 supra.

163. 18 U.S.C. $\& 78 q(a)(1976)$.

164. 428 F. Supp. 483 (S.D.N.Y. 1977), rev'd, 592 F.2d 617 (2d Cir. 1978), rev'd, 442 U.S. 560 (1979).

165. Id.

166. 592 F.2d 617 (2d Cir. 1978).

167. 442 U.S. 560 (1979).

168. E.g., Santa Fe Indus., Inc. v. Green, 430 U.S. 462, 477 (1977); Ernst \& Ernst v. Hochfelder, 422 U.S. 185, 201 (1976). 
the Commission. By its terms, section 17(a) imposes reporting requirements only upon broker-dealers and nowhere mentions accountants. Although the Supreme Court in Touche Ross no doubt was correct in holding that Congress did not intend a private remedy under the section, an alternate, and possibly preferable, ${ }^{169}$ ground for decision would have been to hold, as did the district court, that the accountant had simply not engaged in any conduct prohibited by the statute.

\section{CONCLUSION}

This Article has argued that recent Supreme Court decisions require questions of liability under the securities laws to be determined by reference to the relevant statutory language, structure, and legislative history. Courts which have imposed secondary hability on aiding and abetting, conspiracy, or respondeat superior theories have relied upon none of these tools of statutory construction. Rather, these courts have improperly incorporated various common law doctrines into the securities laws without any attempt to reconcile the imposed liability with the statutory language or its structure.

The proper inquiry, and, mdeed, the only relevant inquiry, is whether Congress intended to prohibit the challenged conduct in question. When congressional intent, as determined by the language, structure, and legislative history of a statute is used as the touchstone of liability, the proper range of defendants subject to liability under section 10 (b) and rule 10b-5 contracts dramatically. Thus, various classes of defendants who have previously been held to be secondarily hable, sucl1 as lawyers or accountants who fail to "blow the whistle," einployers who do no inore than einploy wrongdoers, and banks which knowingly finance a wrongdoer, should no longer be held hable since they have not engaged in any conduct prohibited by the statute.

There no doubt will be some, and perhaps inany, who will regard the proposed approach as overly restrictive and insensitive to the needs of unprotected investors. It inust always be remembered, however, that the primary responsibility for defining the scope of prohibited conduct under a statute and the reinedy for violations of such prohibitions rests with Congress and not with the courts. While this primciple is self-evident, courts have ignored it in implying a private right of action for damages under section 10(b), rule 10b-5, and other securities laws, even though Congress probably never intended such a result. This error should not be coinpounded by continued recogmition of the various forms of secondary liability.

169. See text accompanying note 81 supra. 